\title{
RHESUS NEGATIVE WOMAN TRANSFUSED WITH RHESUS POSITIVE BLOOD: SUBSEQUENT NORMAL PREGNANCY WITHOUT ANTI D PRODUCTION
}

\author{
E.T. MAYA ${ }^{1}$, K. A. BUNTUGU ${ }^{2}$, F. POBEE ${ }^{2}$, and E.K. SROFENYOH ${ }^{2}$ \\ ${ }^{1}$ School Of Public Health, University Of Ghana, Accra, Ghana, ${ }^{2}$ Department of Obstetrics and Gynaecology, \\ Ridge Regional Hospital, Accra, Ghana
}

DOI: http://dx.doi.org/10.4314/gmj.v49i1.11

Corresponding Author: Dr. Ernest Tei Maya

Conflict of Interest: None declared

\section{SUMMARY}

Clinicians sometimes are confronted with the challenge of transfusing haemorrhaging Rhesus ( $\mathrm{Rh}$ ) $\mathrm{D}$ negative patients with $\mathrm{Rh} \mathrm{D}$ positive blood to save their lives. There are concerns about alloimmunization and future haemolytic disease of the newborn in women of the reproductive age. Another fear is transfusion reaction if they receive another $\mathrm{Rh} D$ positive blood in future. We present a 32-year-old $\mathrm{Rh} \mathrm{D}$ negative woman, who had postpartum haemorrhage in her first pregnancy and was transfused with Rh D positive blood because of unavailability of $\mathrm{Rh} D$ negative blood. She did not receive anti D immunoglobin but subsequently had a normal term pregnancy of an $\mathrm{Rh}$ positive fetus without any detectable anti D antibodies throughout the pregnancy. In life threatening situations from obstetric haemorrhage, transfusion of $\mathrm{Rh} D$ negative women with $\mathrm{Rh} D$ positive blood should be considered as the last resort.

Keywords: Rhesus negative, alloimmunization, pregnancy, blood transfusion, anti D immunoglobulin

\section{INTRODUCTION}

Clinicians sometimes are confronted with the challenge of transfusing Rhesus ( $\mathrm{Rh}$ ) D negative patients with $\mathrm{Rh}$ D positive blood under critical conditions to save life. This is more so in women of the reproductive age because of the fear of Rhesus alloimmunization and subsequent haemolytic disease of the newborn. Another concern is future transfusion reaction if they receive $\mathrm{Rh}$ $\mathrm{D}$ positive blood transfusion again.

These concerns may lead to delay in transfusing $\mathrm{Rh} \mathrm{D}$ negative patients with $\mathrm{Rh} \mathrm{D}$ positive blood, which can result in severe morbidity or even death. About $20 \%$ of volunteer $\mathrm{Rh} \mathrm{D}$ individuals given $500 \mathrm{ml}$ of $\mathrm{Rh} \mathrm{D}$ positive blood will not seroconvert ${ }^{1}$ and for individuals needing blood transfusion about $70 \%$ will not seroconvert. $^{2}$
Email: maya_ernest@yahoo.co.uk

We present a 32-year-old $\mathrm{Rh} \mathrm{D}$ negative para 2 woman with a prior $\mathrm{Rh} \mathrm{D}$ positive blood transfusion without anti D immunoglobin. She had a subsequent normal term pregnancy with no detectable anti D antibodies throughout the pregnancy. She was managed at the Regional Hospital, Ridge-Accra.

The aim of this paper is to share our experience with other health care providers.

\section{Case report}

Madam VD 32 years, G2 P2 was first seen at the Ridge Hospital Accra, on 26/5/12. She had been referred from a polyclinic as a case of primary postpartum haemorrhage $(\mathrm{PPH})$ due to retained placenta. She had had a spontaneous vaginal delivery at 5.40am and arrived at the Ridge hospital at 8.30am.

The estimated blood loss according to her medical records was $500 \mathrm{ml}$. Treatments given before referral included intramuscular oxytocin 10IU, intravenous fluid (IVF) $1000 \mathrm{ml}$ Ringers lactate and $500 \mathrm{ml}$ Normal saline. Her vital signs recorded at the time of referral were: temperature $36^{\circ} \mathrm{C}$, blood pressure (BP) $80 / 40$ $\mathrm{mmHg}$. No records on her pulse and respiratory rate (RR) were given. The baby was a $2.6 \mathrm{~kg}$ male with Apgar scores of 7 at 1 minute and 8 at 5 minutes. Besides the information in the referral, we had no more details of her medical records.

On arrival at the Ridge hospital, she was unconscious and her clothing was heavily soaked with blood. Her conjunctiva was very pale; she was not cyanosed or jaundiced. She had deep sighing respiration with a RR of 14 cycles/minute and the chest was clinically clear. The pulse and BP were unrecordable.

The uterus was 24 weeks (wk.) size and flabby. Digital vaginal examination showed the cervix was $5 \mathrm{~cm}$ dilated. The placenta was in situ with the umbilical cord torn. 
A urethral catheter was in situ but there was no urine in the bag. She had one IV line on but the fluid had finished. We estimated that she had lost at least $2000 \mathrm{ml}$ of blood.

Resuscitation was started with crystalloids and oxygen was given by face mask. A second IV line was set up and blood for grouping and cross matching was taken. Manual removal of the placenta was done and about $200 \mathrm{ml}$ of blood clots were also expelled from the uterus. Intravenous ergometrine $0.5 \mathrm{mg}$ was given and $600 \mu \mathrm{g}$ misoprostol was inserted rectally. There was no further bleeding per vaginum thereafter. The haemoglobin $(\mathrm{Hb})$ checked with URIT - 12 Hemoglobin meter was below the detection level of the machine, which is $4.0 \mathrm{~g} / \mathrm{dl}$ (URIT Medical Electronics, Guangxi, China).

A request was made for one unit of group specific uncross matched blood while waiting for the cross matching. Her blood group turned out to be $\mathrm{O} \mathrm{Rh} \mathrm{D}$ negative but there was no $\mathrm{O}$ negative blood available. A request was made for uncross matched $\mathrm{O} R \mathrm{Rh}$ positive blood and she was transfused with $500 \mathrm{ml}$ of it. She later had three units of $\mathrm{O} \mathrm{Rh} \mathrm{D}$ negative blood transfused over the next 18 hours. This was her first blood transfusion. She did not receive anti $\mathrm{D}$ immunoglobin because of financial constraints. She produced about $800 \mathrm{ml}$ of urine over the next 24 hours. She was covered with broad-spectrum antibiotics.

She developed both retrograde and anterograde amnesia. It took 48 hours for her to remember her name and could also not recount what happened within the first 24 hours of admission. She was discharged home on the $7^{\text {th }}$ day with an $\mathrm{Hb}$ of $7.5 \mathrm{~g} / \mathrm{dl}$. She was given oral haematinics. She was counselled on the fact that the incompatible $\mathrm{Rh} \mathrm{D}$ positive blood transfusion could lead to sensitization and subsequent transfusion reaction in case of future $\mathrm{Rh} \mathrm{D}$ positive blood transfusion. In addition future children may suffer from haemolytic disease of the newborn.

It was therefore important for her to inform her health care providers about the incompatible blood transfusion wherever she will be. Both the obstetricians and the neurosurgeon followed her up for the first six weeks. Further follow-ups were done by the neurosurgeon alone for another six weeks. At the twelve-week review, she was given a four-week appointment but did not turn up.

\section{History of current pregnancy}

The next time she was heard of was when she called the lead author to inform him that she was three months pregnant and want to start antenatal care. She was first seen on $2 / 4 / 13$. On examination, she looked well and her general condition was satisfactory. Her pulse rate was 78 beats/min with a BP of $110 / 80 \mathrm{mmHg}$. The uterus was about 14 weeks' size pregnancy.

A diagnosis of Pregnancy in a Rhesus $D$ negative woman with prior Rh D Positive blood transfusion was made. Laboratory investigations requested and the reports were as follows:

$\mathrm{Hb}-14.0 \mathrm{~g} / \mathrm{dl}$, Sickling -Negative, Blood group - O Rhesus D Negative, VDRL - Non reactive, Hepatitis B surface antigen screen - Negative, G6PD screen- No defect, Indirect antiglobulin (Coombs) test- Negative, HIV I\&II screen-Non Reactive, Stool and urine routine exams- Normal,

An obstetric ultrasound scan done on 25/4/13 reported of a single viable intrauterine pregnancy, normal liquor volume, posterior placenta, the average gestational age was 16 wk 2 days and the expected date of delivery was 9/10/2013.

Subsequent care: The antenatal period remained uneventful. She received intermittent preventive treatment for malaria, tetanus toxoid and oral haematinics. Further indirect Coombs tests done at 28, 31, 34 and 38wk were all negative. Two subsequent obstetric scans done showed normal fetal growth with no abnormalities. The $\mathrm{Hb}$ was $12.8 \mathrm{~g} / \mathrm{dl}$ at $38 \mathrm{wk}$.

At 38wk 3 days of gestation, she went into spontaneous labour. The cervical dilatation remained $4 \mathrm{~cm}$ after 10hours despite oxytocin augmentation and was delivered by caesarean section. The baby was a female, weighed $3.0 \mathrm{~kg}$ with Apgar scores of 8 and 9 at 1 and 5 minutes respectively.

The baby's blood group was A Rh D positive. The mother received a single dose of Anti D immunoglobulin $(300 \mu \mathrm{g})$. The baby was monitored clinically for 4 weeks and she did not develop neonatal jaundice.

\section{DISCUSSION}

Obstetric haemorrhage is a leading cause of maternal mortality in Ghana ${ }^{3}$ and getting sufficient Rh D negative blood in time for the haemorrhaging $\mathrm{Rh} \mathrm{D}$ negative parturient can be a challenge.

Among the blood group systems, the $\mathrm{Rh}$ system is the most complex and the $\mathrm{D}$ antigen is second to the $\mathrm{ABO}$ in terms of immunogenicity ${ }^{4}$. Generally, individuals who are Rh D negative do not express the RHD gene. ${ }^{5}$ 
However some Africans and Japanese with Rh D negative phenotype have the RHD gene. ${ }^{6,7}$ Some individuals also express a very limited amount of the D antigen and are classified as weak D.

These individuals are actually $\mathrm{Rh} \mathrm{D}$ positive and are not likely to produce anti $\mathrm{D}$ antibodies when exposed to Rh D positive blood. ${ }^{8}$ They can safely be transfused with $\mathrm{Rh} \mathrm{D}$ positive blood without receiving anti $\mathrm{D}$ immunoglobin. 8,9

The incidence of $\mathrm{Rh} \mathrm{D}$ negative among blood donors in Kumasi, Ghana is $8 \%$. Among the donors were $31 \mathrm{Rh}$ $\mathrm{D}$ negative individuals with $6.4 \%$ of them being weak D. None of the weak Ds were females which could be due to the small number of females; only six. ${ }^{10}$ This brings to the fore the need to further investigate individuals who are found to be $\mathrm{Rh} \mathrm{D}$ negative by the routine serological test to identify those who are weak D before labeling all of them as Rh D negative.

At the first exposure to $\mathrm{Rh} \mathrm{D}$ positive blood, $\mathrm{Rh} \mathrm{D}$ negative individuals who will seroconvert produce small amounts of IgM albeit transient. With a second exposure the reaction is rapid with the production of IgG and as little as $0.03 \mathrm{ml}$ of $\mathrm{Rh} \mathrm{D}$ positive red blood cells (RBC) can elicit a secondary response. ${ }^{4}$

Madam VD was transfused with Rh D positive blood because she was in a critical state and no $\mathrm{O} \mathrm{Rh} \mathrm{D}$ negative blood was immediately available. At presentation she was in shock, had air hunger (deep sighing slow RR of 14) and anuria. We estimated the total blood loss to be at least $2000 \mathrm{ml}$ as it has been established that patients with obstetric haemorrhage in this state have lost between $2000 \mathrm{ml}$ to $3000 \mathrm{ml}$ of blood. ${ }^{11}$

To prevent alloimmunization, she should have been given anti D immunoglobin. About $20 \mu \mathrm{g}$ of anti D immunoglobin is needed per $1 \mathrm{ml}$ of $\mathrm{Rh} \mathrm{D}$ positive $\mathrm{RBCs}^{1}$. About $220 \mathrm{ml}$ of packed RBCs are contained in $500 \mathrm{ml}$ of whole blood ${ }^{12}$ which means Madam VD required $4400 \mu \mathrm{g}$ which she could not afford. We gave her anti $\mathrm{D}$ immunoglobin in the index pregnancy because we do not know why she did not seroconvert after the blood transfusion.

One of the possible explanations for her failure to seroconvert could be that she has a weak D. Factors that can affect the determination of one's Rh D status include the type of method used and type of monoclonal antibodies in the reagent which may have differential reactivity with the different $D$ antigen variants ${ }^{8,13}$ The routine serological test use to determine the $\mathrm{Rh} D$ factor for blood typing would identify weak D as D nega- tive. ${ }^{14}$ RHD polymerase chain reaction (PCR), a facility which our hospital lack is needed to detect weak D. ${ }^{12}$ Even if the facility exists, it is not practical to use in such emergencies. Moreover, there are limitations with the PCR as some Africans and Japanese with Rh D negative phenotype have the RHD gene. ${ }^{6,7}$

Assuming Madam VD is actually true $\mathrm{Rh} \mathrm{D}$ negative; other factors could explain why she did not seroconvert. The ability for an individual to produce antibodies to a given antigen depends on the individual's immune response, the amount of antigen exposed to, the route of administration and the immunogenicity of the antigen. ${ }^{4}$

Polymorphism of the immune response genes affects an individual's ability to produce antibodies ${ }^{15}$. HLAantigens are crucial for cell to cell interaction in antibody production and high anti-D titers, have been linked to certain HLA-DR types. ${ }^{16}$ Thus an individual's genetic predisposition may prevent the one from producing antibodies if exposed to a given antigen. ${ }^{17}$

With regards to its immunogenicity and volume needed to cause sensitization, the D antigen is very immunogenic and parenteral administration of $\mathrm{Rh} \mathrm{D}$ positive $\mathrm{RBC}$ volumes as little as $0.1 \mathrm{ml}$ is capable of causing sensitization in $\mathrm{Rh} \mathrm{D}$ negative individuals. ${ }^{18}$ Hence the about $220 \mathrm{ml} \mathrm{Rh} \mathrm{D}$ positive RBCs received by Madam VD was enough to cause sensitization.

Dutton et $\mathrm{al}^{19}$ observed a decrease in seroconversion in $\mathrm{Rh} \mathrm{D}$ negative patients in shock who were transfused with Rh D positive blood and suggested that this might be due to the immunosuppression associated with haemorrhagic shock. This could also explain why Madam VD did not seroconvert.

Our management of Madam VD had two limitations. The first was our inability to rule out weak D which was due to lack of the facility to do that. The second is the fact that the detection of anti D antibodies were done only by the indirect Coombs test technique. This technique is less sensitive than the enzyme test using papain. ${ }^{20}$ Clinically however, the most important indicator for primary sensitization is the production of antibodies in subsequent pregnancies. ${ }^{21}$ Even in cases where the primary response is weak, the secondary response is vigorous and failure of a secondary response is the ultimate proof of failure of primary immunization. $^{20}$

Madam VD's second child is RH D positive. Fetomaternal haemorrhage in pregnancy is almost univer$\mathrm{sal}^{22}$ and very small volumes of blood could elicit a secondary immune response $e^{4}$ 
We therefore anticipated that if Madam VD was sensitized she would have produced antibodies as the pregnancy progressed. The failure to detect anti D antibodies may be the proof of non-immunization on her part.

\section{CONCLUSION}

Rhesus alloimmunization is not automatic when $\mathrm{Rh} D$ negative individuals in shock are transfused with $\mathrm{Rh} D$ positive blood. In life threatening situations from obstetric haemorrhage, transfusion of $\mathrm{Rh} D$ negative women with Rh D positive blood should be considered as the last resort.

\section{ACKNOWLEDGEMENT}

This article is dedicated to the memory of Dr K.A Buntugu (second author) who unfortunately passed on in October 2014 after the submission of the manuscript.

\section{REFERENCES}

1. Pollack W, Ascari WQ, Crispen JF, O'Connor RR, Ho TY. Studies on $\mathrm{Rh}$ prophylaxis II. Rh immune prophylaxis after transfusion with Rh-positive blood. Transfusion 1971; 11(6): 340 - 344

2. Frohn C, Dümbgen L, Brand J-M, Görg S, Luhm J, Kirchner H. Probability of anti-D development in $\mathrm{D}-$ patients receiving $\mathrm{D}+\mathrm{RBCs}$. Transfusion 2003;43(7) $893-898$

3. Ghana Maternal Health Survey 2007. Calverton, Maryland: GSS, GHS and Macro International pp $31-40$

4. Urbaniak S.J. Alloimmunity to $\mathrm{RhD}$ in humans. Transfus Clin Biol 2006; 3(1,2): 19 - 22

5. Avent ND, Reid ME. The Rh blood group system: a review. Blood 2000; 95: 375-387

6. Daniels G, Green C, Smart E. Differences between $\mathrm{Rh}$ D-negative Africans and Rh D-negative Europeans. Lancet 1997; 350: 862 - 863

7. Okuda H, Kawano M, Iwamoto S, Tanaka M, Seno T, Okubo Y, Kajii E. The Rh gene is highly detectable in Rh-negative Japanese donors. J Clin Invest 1997; 100: $373-379$

8. Westhoff CM. The structure and function of the Rh antigen complex. Semin Hematol 2007; 44:4250

9. American College of Obstetricians and Gynecologists. Practice bulletin: prevention of RhD alloimmunization: clinical management guidelines for obstetricians and gynaecologists. Int J Gynaecol Obstet. 1999; 66:63-70

10. Opoku-Okrah C, Amidu N, Amoah-Sakyi S. Detection of Weak D (Du) Phenotype among Rh-
D negative males and females in Kumasi, Ghana. JUST(GHANA) 2008; 28(3): $34-40$

11. Coker A, Oliver R. Definitions and classifications. In B-Lynch C (ed). A Textbook of Post-Partum Hemorrhage: A comprehensive Guide to Evaluation, Management, and Surgical Intervention. New Delhi: Jaypee Brothers Medical Publishers, 2006 pp 12 - 16

12. Wagner FF. RHD PCR of D-negative blood donors Transfus Med Hemother 2013; 40:172-181

13. Williams M. Monoclonal reagents for rhesus-D typing of Irish patients and donors: a review. $\mathrm{Br} J$ Biomed Sci. 2000; 57:142-149

14. Chen Q, Li M, Li M, Lu XS, Lü R, Sun J, Liu Z. Molecular basis of weak D and DEL in Han population in Anhui Province, China Chin Med J 2012; 125(18):3251-3255

15. Bochud PY, Bochud M, Telenti A, Calandra T. Innate immunogenetics: a tool for exploring new frontiers of host defence. Lancet Infect Dis. 2007; 7: 531-542

16. Hilden J.O, Gottvall T, B. Lindblom B. HLA phenotypes and severe $\mathrm{Rh}$ (D) immunization Tissue Antigens 1995, 46: 313-315

17. Kubistova Z, Mrazek F, Petrek M. Polymorphisms of the immune response genes: selected biological, methodical and medical aspects. Biomed Pap Med Fac Univ Palacky Olomouc Czech Repub 2009, 153(2):93-102

18. Lubusky M. Prevention of $\mathrm{RhD}$ alloimmunization in $\mathrm{Rh} \mathrm{D}$ negative women. Biomed Pap Med Fac Univ Palacky Olomouc Czech Repub 2010; 154(1): $3-8$

19. Dutton R.P, Shih D, Edelman B.B, MD, John Hess J, Scalea T.M. Safety of Uncrossmatched Type-O Red Cells for Resuscitation from Hemorrhagic Shock. J Trauma 2005;59:1445-1449

20. Zipursky A, Israels LG. The pathogenesis and prevention of Rh immunization. Can. Med Assoc J 1967; 97(21): 1245 - 1257.

21. Lloyd Jones M, Wray J, Wight J, Chilcott J, Forman K, Tappenden P, Beverley C. A review of the clinical effectiveness of routine antenatal antiD prophylaxis for Rhesus-negative women who are pregnant. $\mathrm{Br} J$ Obstet Gynaecol 2004; 111:892-902

22. Bowman J. The management of hemolytic disease in the fetus and newborn. Semin Perinatol 1997; 21(1): $39-44$. 